\title{
The Overthrusts of the Trans-Alai and Alai Chains.
}

By Prof. D. J. Mushketov, Director of the Comité Géologique of the U.S.S.R.

THE great plains which run south-eastward from the Sea of Aral contract to the basin of Ferghana, which lies between the great crescentic curve of the Thian Shan to the north, and a series of chains which abut against the Pamir and the mountainous northern projection of Western India. It was shown by J. V. Mushketov, by surveys between the years 1874 and 1880 (described in his "Turkestan," 1886), that in the Alai Mountains the Palæozoic rocks were overturned in many places, and rocks that are not normally in contact had been brought together over wide areas. These facts were not followed up at that time nor by the systematic survey of Turkestan, which began in 1909. That survey showed that in addition to the Palæozoic rocks being overturned northward the Alai chain is traversed by large fault lines with surfaces sloping southward, and that its Kainozoic and Cretaceous deposits show in many places a paradoxical dip under the Palæozoic, and that exotic cap-shaped masses of the Palæozoic rest on younger rocks.

The geological survey of the Ura-Tuba region, that is, of the northern slope of the Turkestan chain between the valleys of Liaïliak and Zaamin Rivers, which I began in 1925, added much to the information regarding the eastern Ferghana: and the study of the numerous northerly curving Palæozoic bandshaped horsts prove the predominance of pressure from the south during the Kainozoic orogenetic processes. These preliminary observations were verified and completed in 1926 by my collaborator, A. P. Markowski, and later in 1927 by myself from the clear sections along the Liailiak River.

The fundamental element of the tectonic structure in this area appears to be an inclination towards the north of long band-shaped Palæozoic blocks which trend west and east and are uplifted at the southern end and plunge downward at the northern end.

The formation of some oblong depressions (Rhabat, Bujun, and others) and many morphological peculiarities of the region appear to result from the mechanism which produced this widespread basin structure.

The second series of interesting observations were made during the past summer (1927) in the second part of my journey across the intersection of the Trans-Alai chain, along the Altyn-Dara River, and along the northern slope of the chain from the summit Khtai-Saz to Mt. Kaufmann, 26,000 ft. high.

The western part of the Trans-Alai chain is more complicated and interesting than the eastern part, and fully confirms the already known discordance between the structure of the eastern, or rather the middle part-the Kyzylart, and that of the Peter the Great Mountains.

These observations lead me to the following conception of the structure of the northern slope of this part of the Trans-Alai chain. It is a large isosyncline (about $3 \mathrm{~km}$. wide) which is highly overturned to the north, and is lying almost horizontal ; it consists largely of Lower Mesozoic red flaggy sandstones, which rest discordantly upon a base that consists of Upper Silurian limestones and that rises slightly above the floor of the valley. The core of this syncline is highly crumpled and includes 16 to 20 steep fanshaped folds of Upper Cretaceous and Eocene marls and clays ; they are raised by this folding to a height of 18,000 ft. in Mt. Khtai-Saz and other peaks. The southern limb of the syncline is truncated by the overriding from the south of the Lower Cretaceous red series, which, in their turn are overridden by the
Palæozoic beds containing effusive rocks that form the southern slope of the Trans-Alai chain.

Probably, moreover, the whole mass of the Trans. Alai chain, together with its Palæozoic base, was overthrust on to the Alai chain, thus occasioning the southward slope of the Alai chain while a large longitudinal displacement began the formation of the Alai valley. The morphological evidence of this fact, announced in 1903 by the American geologist Pum. pelly, is now supported by direct geological proof, by the inclination and disappearance under the Alai valley of the Cretaceous and Kainozoic series of its northern bank (Daraut, Gaz, Sake-Yar). There, of special interest, is the sharp turn of the syncline from an east to west into a meridional strike, accompanied by an overturn to the north; for this change in direction is a supplementary proof of the influence of the southern or Pamir (Alpine) pressure. This change in direction takes place east of the meridian of Mt. Kaufmann, in accordance with the beginning of the curvature of the whole Alai chain into the 'Ferghana flexure.'

Observations on the southern limb of the flexure, between the Alai valley-along the Taldyk River, the southern Yagatch-art and the valleys of KattaKarakol, Ak-bosagha and Archat--prove the occur. rence (along an extent of about $100 \mathrm{~km}$., from the mouth of the Kara-Kavak River, and extending up the southern slope of the Alai to its crest, and farther, beyond Yagatch-art, down the northern slope of the chain) of a large overthrust sheet of the massive Lower and Middle Devonian limestones. This sheet has been followed from south to north, and these limestones are in an absolutely abnormal position, as they lie above the Kainozoic and Cretaceous series and are in apparent accordance with them.

The width of the overriding and the thickness of the masses intersected by it diminish from west to east, in such a manner that on the west the younger series are generally squeezed out and are absent; and then gradually along the overridden band appear younger and younger series, first Cretaceous and finally Tertiary. Thus, to the east of Ak-bosagha, the Devonian deposits lie beneath red sandstones and conglomerates that are very high in the Kainozoic. The surface of the overriding sheet dips distinctly $35^{\circ}$ S.E.

The observations of the past season complete the previous data and entirely confirm the conclusions which I have expressed at different times, particularly as to the 'Pamir orogenesis,' and also my preliminary diagrammatic section from the Pamirs through the Alai up to Ferghana (Izvestia Comité Géologique, 1926, No. 1).

The important observations of the recent Pamir expedition of the Comité Géologique of the U.S.S.R. under the leadership of Prof. D. V. Nalivkin are entirely in agreement with those previously mentioned. Prof. Nalivkin has conclusively proved the arch-shaped bending to the north of all the tectonic elements of the Pamir described by myself in 1917, and that the structure consists exclusively of Mesozoic and Tertiary series with Palæozoic rocks overriding them to the west of Kyzylarchat; he has discovered marine Jurassic deposits at the base of a Mesozoic complex along the Markansu valley, and has shown the analogy of the Jurassic formations of the Pamir with those of Western Bukhara; he has also proved the presence of Mesozoic rocks in the region of MusKol ; and, finally, he has confirmed the general overriding of the whole Pamir system northward. 